\title{
Beérkezett könyvek
}

\section{PSZICHOLÓGIATÖRTÉNET}

Zemplén Gábor Áron: Törékeny spektrum. Newton érvei és az autoritás képzôdése hálózatokban. Budapest, Typotex, Loisir, 2015, 243 oldal, $3200 \mathrm{Ft}$

A tudománytörténész könyve két szempontból érdekes a pszichológusok számára is. Bemutatja Newtonnak a prizmahatások elemzésére vonatkozó színelméleteit, s azok elfogadtatására vonatkozó taktikázásait. Eközben végig ott kísért az a kérdés, végtelen számú szín van-e vagy vannak alapszínek. A 19. század közepétôl ez az utóbbi válik a fiziológiai és pszichológiai színelméletek alapkérdésévé. Másrészt Newton és egy kis kirándulásban Chomsky retorikai eljárásainak elemzése izgalmas példa arra, hogyan bontakoznak ki értelmezési sémák vita és érvelés során.

Csunderlik Péter: Radikálisok, szabadgondolkodók, ateisták. A Galilei Kör története (19081919) Budapest, Napvilág, 400 oldal, 3900 Ft

Igen alapos történészi feldolgozás a századelô egyik máig tanulságos fiatal értelmiségi „klubjáról”. A nagy levéltári munka s a széles perspektíva szembesítés a történészek számára, azért érdekes, mert meghaladja a konzervatív (Szekfú Gyula, Tormai Cecil) s a baloldali (Rákosi Mátyás, Kende Zsigmond) értelmezések közös gondolatáét, a Galilei Kör a magyar kommunista mozgalom és a Tanácsköztársaság elôkészítője. A gazdag tartalmi bemutatás a pszichológusok számára két tekintetben érdekes. Visszaadja a kor szellemi pezsgését. A sok forrongó új gondolat közt a visszatérô antiklerikalizmus és az iskolaalakító álmok máig tanulságosak. Kicsit tömören, de a szerző ugyanakkor bemutatja Pikler Gyula, Ferenczi Sándor és Dienes Valéria eloóadásait, illetve szerepét a körben. A tágabb keretbốl pedig igen érdekesek a kezdeti evolucionista ihletések, melyeket gyorsan felvált az átfogó szociologizmus az akkori fiatalok távlataiban.

Katja Guenther: Localization and Its Discontents. A Genealogy of Psychoanalysis and the Neuro Disciplines. Chicago: University of Chicago Press, 2015, 296 oldal, 35 USD

A német szociális aktivista és tudománytörténész könyve friss hangot hoz az agyi lokalizáció történetének kutatásába. A Kurt Danziger által az 1990-es években elindított hagyományt követve a lokalizációs tanítás néhány nagymesterét adatszerzési és elôadási közegükben elemzi. Ez a kontextualizmus a különbözó színterek gazdag elemzését adja. Elsôsorban a 20. század elejére és német ihletésû́ közegekre összpontosít. Hat hôse és hat kerete van. Meynert Bécsben a kórbonctannal, Wernicke a tantermi osztályozással, Freud a reflex elméletek 
meghaladásával, Foerstrer a mozgásterápiákkal, Schilder a testvázlat klinikai elemzésével, Penfield pedig az agysebészeti mútôasztal elemzésével jelenik meg. Sajnos a „latin hagyomány", Broca, Charcot, Janet, Claparède, a spanyolok és olaszok, de az oroszok is hiányoznak. De ne legyünk telhetetlenek. A bemutatott szcénák igen izgalmas olvasmányok.

\section{KOGNITÍV PSZICHOLÓGIA}

Márton Miklós, Molnár Gábor és Tôzsér János (szerk.): Más elmék. Budapest, L’Harmattan, 2017, 277 oldal, $2900 \mathrm{Ft}$

A konferenciakötet igen sokoldalúan járja körül a modern filozófia egyik vaskos paradoxonnak tûnố kérdéskörét. Hogyan lehet eljutni az elsố személyú nézốpontból annak feltételezéséig, hogy rajtam kívül más gondolkodó lények is vannak. 11 dolgozat járja körül ezt Descartes-tal indítva, s javarészt a mai ún. analitikus filozófia megoldásait bemutatva. A záró négy tanulmány üde sziget a pszichológusnak, miután belefáradt abba, hogy miért is kell bizonyítani, hogy mások is vannak. Itt jutunk el a végsố kérdésektôl a hogyanig. Kiss Szabolcs az elmeolvasás és az empátia idegtudományi, Schnell Zsuzsa pedig a becsapás s a viccelốdés helyzeteit használó társalgási elemzését mutatja be. Albert Gábor és Schnell Zsuzsa pedig két tanulmányban elemzik az autizmus és a másik elme probléma kapcsolatát.

Lewis, Michael. The undoing project. A friendship that changed our minds. New York, Norton, 2017, 362 oldal, 28,95 USD

Egy hivatásos tudományos és sportújságíró sikerre jelölt könyve. Személyes, történetek és társadalmi beágyazás köré szervezett bemutatás Tversky és Kahnemann barátságáról. S fôként arról, hogyan alakult ki az a különös együttmúködésük, ahol a döntéselméletet az élet minden területére beviszik. A baseballeredmények jóslásától a palesztin-izraeli harci eseményekig. Kicsit túl jól megírt könyv a szó újságírói értelmében. Az utolsó mondat például. „S akkor megszólalt a telefon”. Mármint akkor, amikor az örök barátja s szerzótársa nélkül maradt Kahnemann azt várja, vajon hívják-e, hogy megkapta a Nobel-díjat. 